\title{
微小重力下における直流電界中での単一液滴燃焼時のすす挙動*
}

\author{
今村 宰*1, 久保康之苂, 大坂 淳*2 \\ 佐藤順一*3, 津 江光 洋 ${ }^{* 4}$, 河野通 方*5
}

\section{Sooting of Single Droplets Combustion in DC Electric Fields under Microgravity}

\author{
Osamu IMAMURA*6, Yasuyuki KUBO, Jun OSAKA, \\ Jun'ichi SATO, Mitsuhiro TSUE and Michikata KONO \\ ${ }^{* 6}$ Graduate School of Frontier Science, The University of Tokyo, \\ 7 3-1 Hongo, Bunkyo-ku, Tokyo, 113-8656 Japan
}

\begin{abstract}
Sooting of single droplets combustion in direct current (DC) electric fields was investigated experimentally using microgravity conditions. The ambient gas was air at atmospheric pressure and room temperature, and toluene was used as a fuel. The distance between electrodes is $50 \mathrm{~mm}$ and applied electric voltages ranged between 0 and $6 \mathrm{kV}$. Soot concentration and flame luminosity, which corresponds to soot radiation, were measured. Soot concentration was estimated using full-field extinction technique. As the applied voltage increased, the amount of soot decreased and the luminosity increased. Considering the distribution of soot concentration and luminosity, we guess changes in soot concentration and luminosity were caused by the movement of soot and its precursor and ionic wind. When applied voltage is less than $2 \mathrm{kV}$ the decrease in the amount of soot was outstanding, which can affect the burning rate constant.
\end{abstract}

Key Words: Liquid Fuel, Flame, Diffusion Combustion, Microgravity, DC Electric Field, Droplet, Soot

\section{1. 緒言}

電界が燃焼に及ぼす影響は様々なものが知られてい るが，その中でも特にすすに及ぼされる影響はよく知 られている(1) (10). Weinberg ら ${ }^{(1)(2)}$ は, 主に対向流拡 散火炎を用いて電界がすす生成に及ぼす影響について 調べ，すす粒子の大部分が正に帯電していることや, 電界がすす生成過程に影䈉を与えることを示している. Kono $5^{(3)}$ も同じく対向流払散火炎に直流および交流 電界を印加することによって，火炎輝度や排出される すす量が複雑に変化していることを報告している．特 に直流電界を印加した場合には影著な耀度および放 出されるすす量の減少を報告している．また，噴流拡 散火炎を用いた研究も多く行われている ${ }^{(6) \sim(8)}$. 新居 $5^{\left({ }^{8}\right)}$ は噴流拡散火炎に軸方向に直流電界を印加して, 火炎温度の上昇およびすす量の隇少を報告している. 彼らは直流電界印加時のすす量の隇少について, イオ

* 原稿受付 2003 年. 5 月 28 月.

*1 学生員, 東京大学大学院新領域創成科学研究科( $-113-8656$ 東京都文京区本郷 7-31)。

*2 東宗大学大学院L学系研究科.

*3 正員, フェロー, 不川島播磨重工業(株) ( 235-8501 横浜市 磯子区新中村 1 ).

*4 正員, 東京大学大学院工学系研究科.

*5 正員, 東京大学大学院新領域㓣成科学研究科.

E-mail : kk37202 (a mail.ecc.u tokyo.ac.jp
ン風による混合促進を一つのメカニズムとして推定し ている.さらに最近では微小重力環境を用いた実験も 行われており, 電界印加による球状拡散火炎の輝度の 低隇が報告されている ${ }^{(10)}$.

一方，すすは液滴燃焼においては燃焼速度定数など の燃焼特性に影響を与えると考えられており ${ }^{(12) \sim(14),}$ 液滴燃焼時に生成されるすすに関する研究は機関の高 効率化などの観点から非常に重要であると思われる. 著者らは過去に微小重力環境を用いて直流電界中で液 滴燃料を燃焼させ，燃焼速度定数が増加することやそ の增分はすすの生成特性によって異なることを報告し た ${ }^{(11)}$. しかしながら, 電界が液滴燃料の燃焼時のす すに及ほす影響については有用な情報が得られていな いため, 電界が燃焼速度定数に及ぼす影響について十 分な議論がなされなかった.

以上のような背景から，本研究は微小重力睘境を用 いて，直流電界が燃料液滴の燃焼時に生成するすすに 及ぼす影響について調べたものである. 微小重力環境 を用いることによって自然対流の影響を取り除くこと ができ，電界の影響を明確にすることが可能である. 生成されたすす量および火炎輝度の計測を行い，実験 結果から電界が燃焼速度定数に及ぼす影響について考 

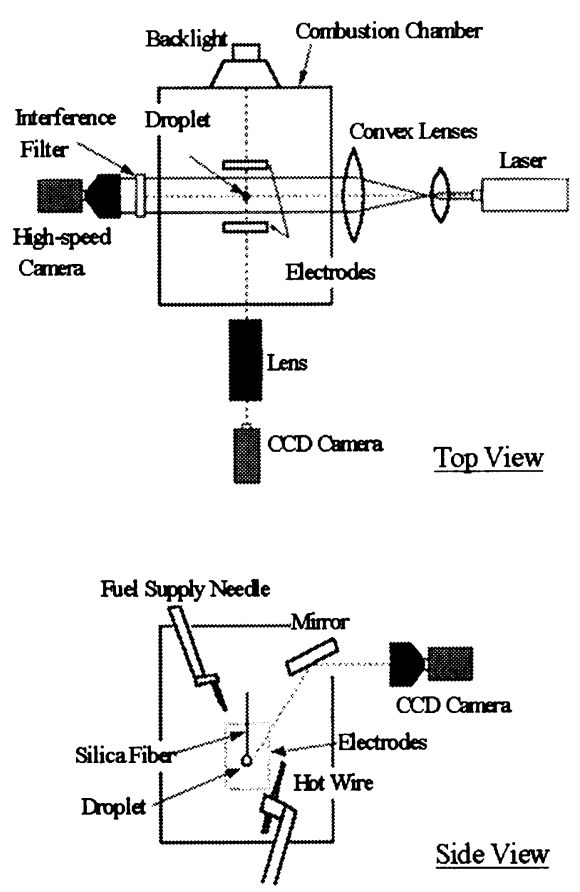

Fig. 1 Experimental apparatus

察を行った. すす量の測定には透過光隇衰法を用いた. 液滴燃焼において電界がすす生成に及ぼす影響は, 電 界が燃焼速度定数に及ぼす影響を考察する上で必要な ばかりではなく，液滴燃焼に及ぼすすすの影響を考察 する上でも重要と思われる. また本研究のような電界 が液滴燃料の燃焼時に生成されるすすに及ほすす影響に 関しては研究報告例がなく，理化学的な観点からも興 味深い.

\section{2. 実跧装貫および方法}

2.1 実験施設およひ実硂装置微小重力環境は すべて東京大学工学部落下塔にて得られた。本落下塔 の実験部は $10 \mathrm{~m}$ であり, 約 $0.9 \mathrm{~s}$ の微小重力徳境を実 現することができる. 良質な微小重力環境を得るため, 落下筐体 (実験装置) を空気抵抗遮断用の外箱と同時に 落下させることによって空気抵抗を極力排しており， 得られる微小重カレベルは $10^{-4} \mathrm{~g}$ 以下である. また制 動部にはスポンジが敷き詰めてある.

落下筐体中央部には, 燃焼容器が備え付けられてお り，その中心部には，燃料液滴を保持するための石英 線がある. 石英線は直径 $0.125 \mathrm{~mm}$, 長さ $40 \mathrm{~mm}$ のファ イバー状であり，先端は液滴を確実に保持するために 直径 $0.32 \mathrm{~mm}$ 程度の球形に加工してある. 石英線近傍
には，液滴を生成する燃料供給針，鉄クロム線を用い た熱面点火装置があり，石英線をはさむように平行に 電極が配してある (図 1). 電極間の間隔 $L$ は, $50 \mathrm{~mm}$ で あり，空気の流れを妨げないため，また撮影を容易に するために電極として金網を用いている. なお落下筐 体には，3台の CCD カメラが搭載されている．1台 は液滴後方からバックライトを照射することにより液 滴像を確認する白黒 CCD カメラ，もう一台は透過光 隇黄法によってすす浱度を観察する高速度カメラ, 最 後の 1 台はミラーを介して火炎 (本稿では輝炎と同義 である) を観察する 3CCD カメラである．透過光隇衰 法を行うため落下筐体には, Nd:YAG レーザー(波長 $532 \mathrm{~nm})$ を搭載している.

2.2 実殹方法および解析手法 まず通常重力下 において, 㦟垂線先端に液滴を生成する.この状態で 電極間に電圧を印加したのち, 実験装置を自由落下さ せる. 実験装置が微小重力状態に移行すると, 制御系 により液滴の点火が行われる. 液滴の燃焼現象を上述 の 3 台の CCD カメラを用いて観察, 録画し, 得られ た画像データから実験結果を得た.

液滴像を観察するカメラからは, 液滴径 $d$ を得た. 液 滴径 $d$ は, 石英線に支持された液滴を回転楕円体とみ なし，長径 $a$ および短径 $b$ から換算した $\left(d \equiv\left(a b^{2}\right)^{1 / 3}\right)$.

高速度カメラからは火炎内のすす浱度に関する情報 を得た. 火炎後方からレーザー光 (波長 $532 \mathrm{~nm}$ ) を照 射し，干涉フィルターを介して撮影した．すす質量浱 度 $C\left[\mathrm{~g} / \mathrm{m}^{3}\right]$ と吸光度 $A$ には以下の関係式がある.

$$
A=-\log \frac{I_{\text {ext }}}{I_{\text {in }}}=C \times l \times Q
$$

ここで $I_{i n}, I_{e x t}$ はそれぞれ試料部通過前後のレーザー 強度, l は試料部の長さ, $Q$ はすすの質量吸収係数で ある. $Q$ が一定であるとすると $A$ は光路方向に積算さ れたすす量を表わすことになるので，以下では吸光度 $A$ を用いてすす量を評価する.

最後に 3CCD カメラからは火炎の輝度情報を得た. しかしながら $\mathrm{R}$ (赤) および $\mathrm{G}$ (緑) 成分については火炎 輝度が非常に強く計測不能となる場所も存在した.こ のため, 火炎輝度の議論については, 3CCD カメラか ら B(青)のみの信号を取り出して議論することとする. なお本実験において火炎を撮影した場合, 各点の輝度 R,G,B は互いに比例関係にあり，その関係は電界の印 加によって大きく変化しなかった. すなわち火炎色の 大きな変化は認められなかった.

2.3 実験条件本実験で用いた燃料はトルエン であり, 雾囲気気体は大気圧室温の空気である. 燃焼 開始時の液滴径 $d_{0}$ は, $0.75 \pm 0.07 \mathrm{~mm}$ の節囲内にあ 


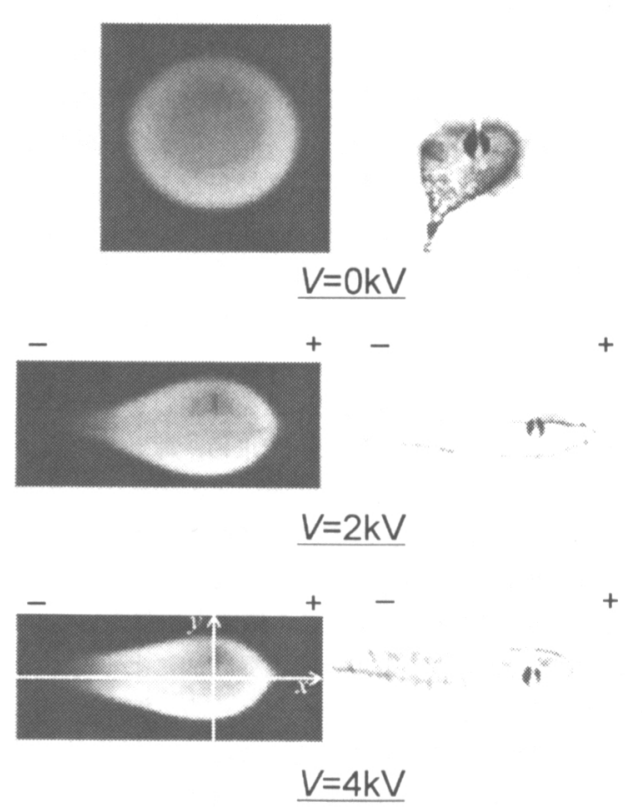

Fig. 2 Direct flame photographs (left) and absorbance distributions (right)

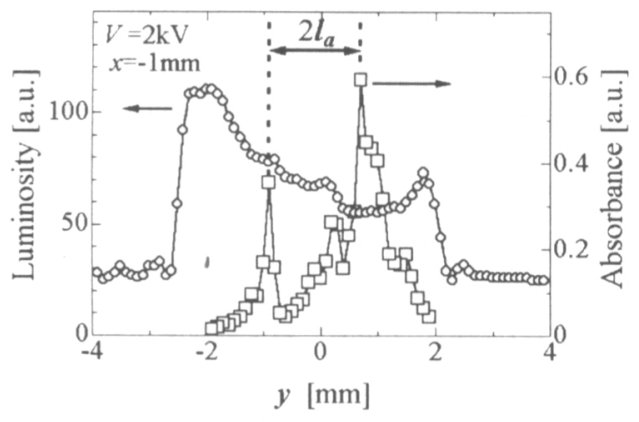

Fig. 3 Flame luminosity and absorbance plotted as a function of $y(V=2 \mathrm{kV}, x=-1 \mathrm{~mm})$

り,この範冊内においては微小重力環境下で全燃焼過 程を観察することが可能である. 印加電圧 $V$ は 0 $6 \mathrm{kV}$ の間で変化させた. 電極間隔 $L$ は $50 \mathrm{~mm}$ である から仮に一様な電界が生じているとすれば, 電界強度 $E(\equiv V / L)$ は 0 から $120 \mathrm{kV} / \mathrm{m}$ の範囲内となる.

\section{3. 実験結果およひ考察}

3.1 すす分布図 2 中の各行左側は火炎の直接 写真, 各行右側は吸光度すなわちすす濃度の分布を示 している，全ての図において，右側に陽極が左側に陰

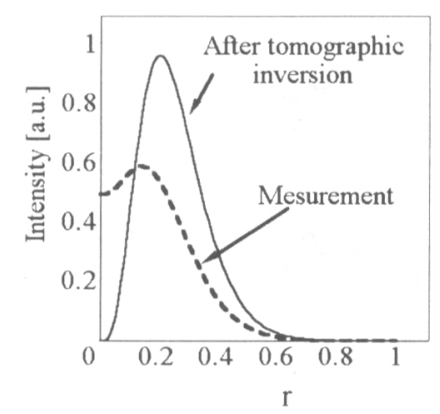

Fig. 4 An example of tomographic inversion

極がある.また各行右側の図において，すす分布の中 心付近に黒く写っているものは液滴である。これらの 図から過去の報告 ${ }^{(11)}$ と同様に, 電界の印加により輝 炎が主に陰極方向に大きく引き伸ばされていることが 確認される. また図からすす殼が変形し, すすが陰極 方向に放出されているのがわかる.

ここで後の議論のために, 図 2 中に示されるように 座標軸を定義する. 座標軸の原点は液滴中心であり, $x$ 軸は電界印加方向で陰極から陽極に向かう向きを正 としている. 図 3 は, 印加電圧 $V=2 \mathrm{kV}, x=-1 \mathrm{~mm}$ に おける吸光度の分布を火炎輝度とともに示したもので ある. この図に示されるように吸光度の分布は火炎輝 度の分布内にほぼ収まっている。また図 3 から, 輝度 が大きな領域では吸光度がほぼ 0 であることから，実 際に明るく輝いているすすは微量であると思われる.

図 3 において, 吸光度は $x$ 軸 $(y=0)$ に関してほぼ対 称な位置に極大値をもっている.このような傾向はほ ぼ全ての場所 $(x)$ について確認されたため, 図 3 に示 されている極大值の位置 $l_{a}$ とその值 $M_{a}$ をすすの分布 の代表值として用いることとする. 液滴を懸垂してい る石英線の影響に起因する非対称性を考虑して, $l_{a}$ に ついては極大值間の距離の半分とし, $M_{a}$ については 2 つの極大值の平均值として定義した．輝度分布に関 しても $l_{i}$ と $M_{i}$ を同様に定義する.

ここで，透過光減衰法によって得られたすす分布は 光路方向に積算された值であり, 断面分布ではない. 本研究で得られた実験データから断面分布を求めるに は, すす分布が軸対称であると仮定し数学的な変換を 行う必要である ${ }^{(13)}$. しかしながら, 本研究における 実験デー夕は図 3 が示すように必ずしも対称性がよい わけではないため, 積算値を用いて分布を見積もるこ ととしたものである. なお図 4 は光路方向の積算值か ら断面分布を求めた例である. 図 4 から, 図 3 のよう 


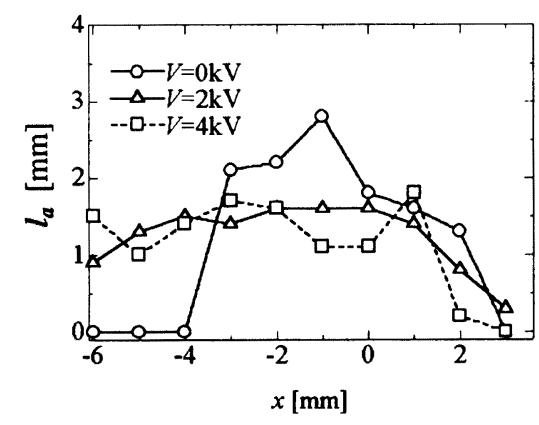

Fig. 5 Positions of absorbance maximum, $l_{a}$, plotted as a function of $x$

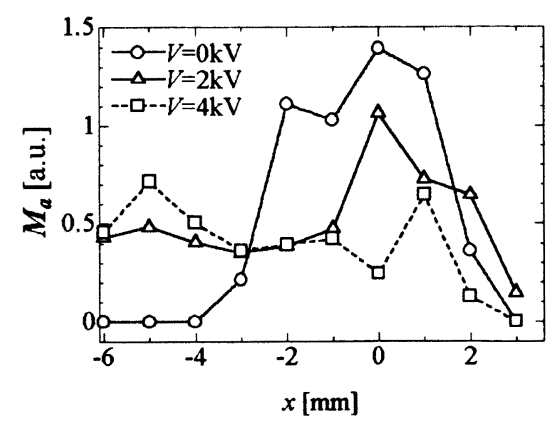

Fig. 6 Absorbance maxima, $M_{a}$, plotted as a function of $x$

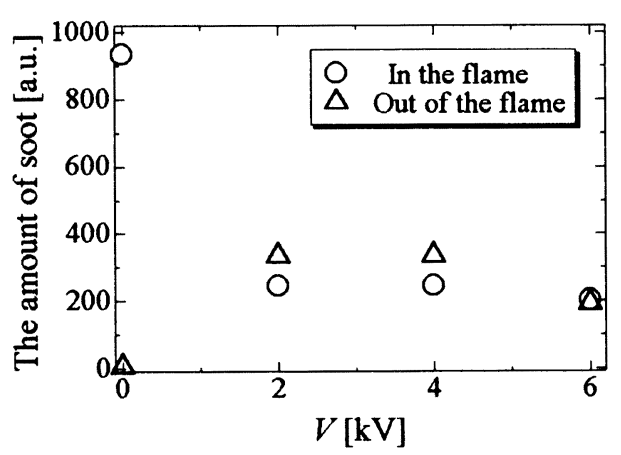

Fig. 7 Flame mean absorbance vs. applied voltage

に急峻な極大值をもつ場合, その断面分布はやや外側 で急峻な極大值をもつと予想できる.

図 5 および図 6 は, $l_{a}$ および $M_{a}$ を $x$ に関してプロッ トしたものである. 図 5 において電界無印加時に $l_{a}$ が
陰極側で大きな值をとっているのは, 図 2 に示される ように点火の影響によりすす款が変形していることに よる.この変形を加味しても, 図 5 から液滴近傍にお いては電界印加により $l_{a}$ がわずかであるが減少して いることがわかる.これはすす款がつぶれるように変 形していることに対応している (図 2). 一方, 図6か ら夜滴近傍において電界印加により $M_{a}$ は顥著に減少 しており, $l_{a}$ の変化に比べ $M_{a}$ は大きく変化している ことがわかる.

図7にはすす量の電圧依存性を示す.すす量は吸光 度 $A$ を空間的に積算することで求め, 戟炎内と戦炎外 に分けて示している. なお液滴による吸光の影掣を除 去するため, $|x|<0.5$ の範囲は積算の対象外としてい る. 輝炎内は $|x|<4 \mathrm{~mm}$ として定義しており, 少なく とも電界無印加時の輝炎はこの範囲内に収まっている. この図から輝炎内のすす量は電界印加によって半分以 下に減少していることがわかる. 一方, 輝炎外部のす す量は電界印加により增加している. しかしながら, その增分は輝炎内での滅少分ほどは大きくなく, 輝炎 内外のすす量を加えると電界印加によってすす量が隇 少していることがわかる. なお図7において火炎内外 のすす量を加えると, $V=0 \mathrm{kV}$ に対して $V=2 \mathrm{kV}$ では 4 割程度のすす量の減少が見られる.

電界印加によるすす量の減少の要因として, 帯電し ているすすやその前駆体がクーロン力を受けて極板方 向に移動し，熱分解領域での滞留時間が短くなること が考えられる. 電界を印加していない場合すす粒子が 高温域に移動できない主なる要因はサーモフレーシス (熱泳動) 効果である. ここで, サーモフレーシス効果 によるドリフト速度と電界によるドリフト速度を簡単 に見積もり比較してみる. 熱泳動速度 $v_{T h}$ は以下の式 で表わされる(15).

$$
v_{T h}=-K_{T} \frac{v}{T} \cdot \frac{d T}{d x}
$$

ここで， $K_{T}$ は熱泳動係数で粒径が小さいほど大きく, その值は最大で 0.54 程度である ${ }^{(15)} . v, T$ はそれぞれ空 気の動粘性係数および温度である.ヘプタン液滴の然 焼研究を参考に ${ }^{(16)}$, 液滴然焼における温度勾配を最大 で $350 \mathrm{~K} / \mathrm{mm}$ と見積ると，熱泳動速度は $20 \mathrm{~mm} / \mathrm{s}$ 程度 となる.一方，電界によるドリフト速度はすすの移動 度と電界強度の積であり，すすの移動度を $3.0 \times 10^{-2}$ $\left[\mathrm{cm}^{2} \mathrm{~s}^{-1} \mathrm{~V}^{-1}\right]$ と仮定すると ${ }^{(2)}{ }^{(4)}, V=2 \mathrm{kV}$ における 電界によるドリフト速度は $120 \mathrm{~mm} / \mathrm{s}$ 程度となる.よっ て電界の印加によって熱泳動の力に逆らって移動する ことは可能であると思われる.

この他のすす隇少のメカニズムとして過去の研究 (8)(9)では, 火炎に直流電界を印加した場合, イオン風 


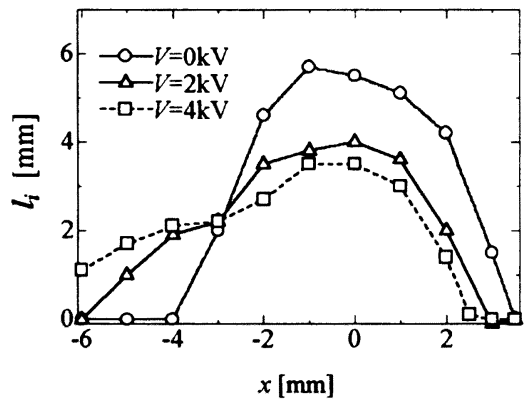

Fig. 8 Positions of luminosity maximum, $l_{i}$, plotted as a function of $x$

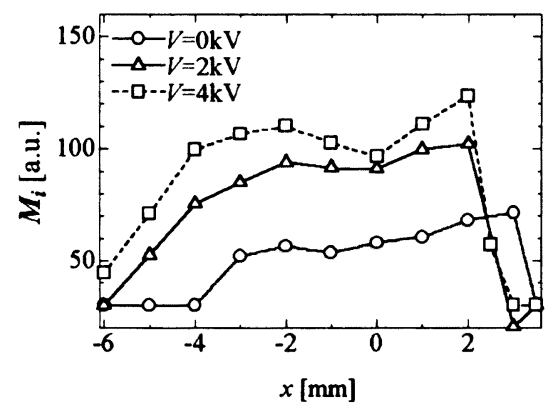

Fig. 9 Luminosity maxima, $M_{i}$, plotted as a function of $x$

によってすすの酸化が促進されることが指摘されてお り, 本実験の箱囲内においてもイオン風による酸化の 影製が考えられる. また瀷炎内でのすす量の隇少には, 図 7 の結果からクーロンカによって単純にすすが火炎 外に放出される効果も寄与していると思われる.

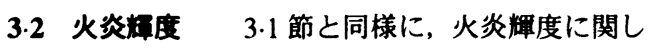
て図 3 中の極大值を用いて $l_{i}$ と $M_{i}$ を定義する. 図 8 および図 9 は, $l_{i}$ および $M_{i}$ を $x$ に関してプロットし たものである. 図8 から, 電界印加によって液滴近傍 で $l_{i}$ が減少していることがわかり，またそれは図 2 に 対応している.この傾向は $l_{a}$ (図 5) と同様である. た だし図 5 と比較するとその減少分は大きく, イオン風 の影䨩が示唆される.一方, 図 9 から $M_{i}$ は $x$ の值に よらず電界の印加と共に增大しており，特に液滴から 離れた場所における彈度上昇が影著である.

次に, 火炎全体での火炎㟕度の平均を印加電圧に対 してプロットしたものが図10である.この図から,電 圧印加に伴い平均の火炎舖度が上昇していることがわ かる. また，この図には火炎投影面積もあわせて示し

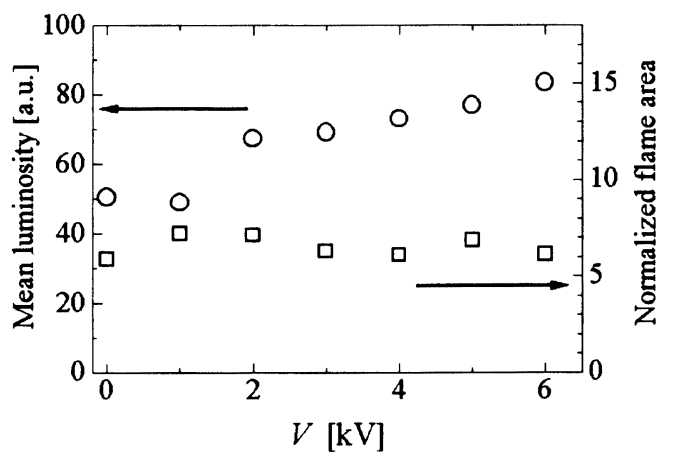

Fig. 10 Mean luminosity vs. applied voltage

ている. 印加電圧に対して火炎投影面積に大きな変化 は見られない. しかし，火炎形状が電界印加方向に対 し概して軸対称であり火炎はその方向に引き伸ばされ ていることから，火炎体積はわずかながらであるが減 少しているものと推測される.

火炎輝度はすすからの放射に依存すると思われ，そ の放射はすす温度とすすの量に依存するものと思われ る. ゆえに, 火炎輝度増加の要因として, すす温度の 上昇あるいは高温域にあるすす量の增加という 2 つが 考えられる. 温度上昇に関しては，それに関する直接 的な証拠は本研究においては得られていない.しかし

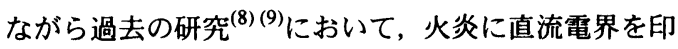
加した場合にはイオン風の役割が重要であることやイ オン風に起因する火炎の温度上昇が指摘されている. 本研究においても火炎の形状から陽極から陰極に向か うイオン風が生じているものと思われ, すす温度の上 昇による影響は無視できないものと思われる.

次にすす量の增大についてであるが， 3.1 節から全 体としてのすす量は滅少しているので, 輝度上昇のメ カニズムとして低温域に存在していたすすが電界の印 加により高温域に移動した可能性が考えられる. 図 6 からすす分布は陰極方向に移動しており, 加えて図 9 から液滴陰極側で彈度上昇が確認されることから，こ れらの輝度上昇は高温部にすすが移動したことに起因 するものが大きいと思われる. また図 2 から陽極に向 かうすす粒子も確認されており, 図 9 中で特に陽極側 で輝度が極端に大きくなっているのは比較的大きなす す粒子が火炎帯を横切っているためと考えられる.

3.3 総括的考察 以上述べてきた実験結果は, 印 加電圧 $V=2 \mathrm{kV}$ を境に様相が異なる. 図 7 および図 10 において，すす量，火炎輝度ともに $V<2 \mathrm{kV}$ で急 激に変化している. $V>2 \mathrm{kV}$ に注目すると, 火炎輝 
度は単調に増加するのに対して, すす量は大きな変化 が認められない，図 5 と図8, 図 6 と図 9 をそれぞれ 比較しても，V>2 kVにおいては, すす量の分布に 多少ばらつきがあるものの電界がすすに与える影響は 小さく, 一方で火炎輝度は着実に電界の影響を受けて いることがわかる. 火炎輝度の上昇に関してはイオン 風による温度上昇とすすの移動の二つの要因について

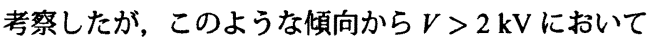
はイオン風が火炎の輝度上昇に及ぼす影響の方が大き いように思われる.

$V<2 \mathrm{kV}$ の領域については, 図 7 からすすの減少 が顕著である. 液滴然焼において火炎中のすすは然 焼速度定数に影䇾を及ぼすことが指摘されているた め $^{(12) \sim(14),}$, 燃焼速度定数に与える影響について考察す る. 著者らは過去に同様の実験装置を用いて, 直流電 界がトルエン燃料の然焼速度定数に与える影留につい て実験的に調べた ${ }^{(11)}$. その結果, トルエンの燃焼速 度定数は, 電界無印加時の败焼速度定数を $K_{0}$ とする と, $V=2 \mathrm{kV}$ で $K / K_{0}=1.3, V=6 \mathrm{kV}$ で $K / K_{0}=1.5$ 程 度であった.このように燃焼速度定数は $V<2 \mathrm{kV}$ の 領域で大きく增加しており，V<2 kVにおける燃焼 速度定数の增分はすすの減少と大きく関わっているも のと考えられる. 過去の研究報告例では, すすが存在 するとそのすすからの放射熱損失によって燃焼速度定 数が隇少するという計算結果が得られている(14). 本研 究においては輝度の上昇が確認されており電界印加に よって放射熱損失が增大していることになるが，燃焼 速度定数はそれに反して増加している. すなわち, 本 研究での燃焼速度定数の増加の要因はすすの減少によ る放射熱損失の低減ではない，燃焼速度定数の増加の 要因としてイオン風による対流の効果や，すす殸によ

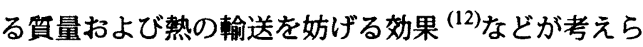
れる. 本研究で用いたトルエンのようなすすを大量に 生成する燃料については, 電界印加によってすす款に よる賀量および熱の輸送を妨げる効果が低減されたと 考えるのが妥当であろうと思われる.

\section{4. 結論}

本研究では, 微小重力環境を利用して直流電界中で トルエン液滴を燃焼させ，電界が燃焼時に生成するす すおよび火炎輝度に及ほす影響について調べた. その 結果, 明らかとなった事項は以下のとおりである.

1. 電界印加により生成されるすす量の隇少が観察さ れ，輝炎内においてはすす量は半分以下に隇少した. これは電界印加によるすすおよびその前駆体の滞留時 間の変化とイオン風による影響が主要因であると考え
られる.

2. 電界印加により, 火炎輝度の上昇が観察された。 これは低温域に存在していたすすが電界の町加によっ て高温域に移動したこと, およびイオン風に起因する すす温度上昇が主なる要因と考えられる.

3.すすを大量に生成する液滴然料の然焼においては, 電界印加によるすすの滅少は然烵速度定数に大きな影 䭗を及ぼすと考えられる.

\section{謝辞}

本研究の一部は,「微小重力環境を利用した然料多様 化対応燃焼技術の研究開発」の一環として, (財)宇宙 環境利用推進センター(JSUP) が新エネルギー・産業 技術総合開発機構 (NEDO) から委託を受けて実施した ものである. また本研究を進めるにあたり, 本学工学 部の内海正文技官, 岩田梯次技官, 学部学生の宿谷弘 樹君にご協力いただいた. 記して謝意を表する.

\section{文献}

(1) Place, E. R., and Weinberg F. J., "Proc. Combust. Inst.", 11(1967), pp.245-255

(2) Mayo, P. J., and Weinberg F. J., "Proc. R. Soc. Lond. A", 319(1970), pp.351-371

(3) Kono, M., Iinuma, K., and Kumagai, S., "Proc. Combust. Inst.", 18(1981), pp.1167-1174

(4) Kono, M., Carleton, F. B., Jones, A. R., and Weinberg, F. J., "Combust. and Flame", 78(1989), pp.357-364

(5) Xie, L., Kishi, T., and Kono, M., "Proc. Combust. Inst.", 24(1992), pp.1059-1066

（6）水谷幸夫, 中原正季, “機酭 (B)”, 49(1983), pp.1530-1538

(7) 田中秀憲, 上原頁, 斎間厚, “機論 (B)”, 60(1994), pp.1168-1175

(8) 新居利洋, 斉藤正浩, 新井雅隆, “機詥 (B)”, 64(1998), pp.3881-3887

(9) 新居利洋, 斉藤正浩, 新井雅隆, “機詥 (B)”, 66(2000), pp.256-262

(10) Yuan, Z., Hegde, U., and Faeth, G. M., "Combust. and Flame", 124(2001), pp.712-716

(11) Ueda, T., Imamura, O., Okai., K., Tsue, M., Kono, M., and Sato, J. "Proc. Combust. Inst.", 29(2002), pp.2595-2601

(12) Jackson, G. S., and Avedisian, C. T., "Proc. R. Soc. Lond. A", 446(1994), pp.255-276

(13) Lee, K., Manzello, S. L., and Choi, M. Y., "Combust. Sci. and Tech.", 132(1998), pp.139-156

(14) Manzello, S. L., and Choi, M. Y., Kazakov, A., Dryer, F. L., Dobashi, R., and Hirano, T., "Proc. Combust. Inst.", 28(2000), pp.1079-1086

(15) 奥山喜久夫, 増田弘昭, 諸岡成治, 微粒子工学, オー 么社, (1992) pp. 106-107

(16) Mikami, M., Niwa, M., Kato, H., Sato, J., and Kono, M., "Proc. Combust. Inst.", 25(1994), pp.439-446 